\title{
Microbial nitrogen fixation and methane oxidation are strongly enhanced by light in Sphagnum mosses
}

Martine A. R. Kox', Eva van den Elzen², Leon P. M. Lamers ${ }^{2}$, Mike S. M. Jetten ${ }^{1}$ and Maartje A. H. J. van Kessel ${ }^{1 *}$

\begin{abstract}
Peatlands have acted as C-sinks for millennia, storing large amounts of carbon, of which a significant amount is yearly released as methane $\left(\mathrm{CH}_{4}\right)$. Sphagnum mosses are a key genus in many peat ecosystems and these mosses live in close association with methane-oxidizing and nitrogen-fixing microorganisms. To disentangle mechanisms which may control Sphagnum-associated methane-oxidation and nitrogen-fixation, we applied four treatments to Sphagnum mosses from a pristine peatland in Finland: nitrogen fertilization, phosphorus fertilization, $\mathrm{CH}_{4}$ addition and light. $\mathrm{N}$ and $\mathrm{P}$ fertilization resulted in nutrient accumulation in the moss tissue, but did not increase Sphagnum growth. While net $\mathrm{CO}_{2}$ fixation rates remained unaffected in the $\mathrm{N}$ and $\mathrm{P}$ treatment, net $\mathrm{CH}_{4}$ emissions decreased because of enhanced $\mathrm{CH}_{4}$ oxidation. $\mathrm{CH}_{4}$ addition did not affect Sphagnum performance in the present set-up. Light, however, clearly stimulated the activity of associated nitrogen-fixing and methane-oxidizing microorganisms, increasing $\mathrm{N}_{2}$ fixation rates threefold and $\mathrm{CH}_{4}$ oxidation rates fivefold. This underlines the strong connection between Sphagnum and associated $\mathrm{N}_{2}$ fixation and $\mathrm{CH}_{4}$ oxidation. It furthermore indicates that phototrophy is a strong control of microbial activity, which can be directly or indirectly.
\end{abstract}

Keywords: Methanotrophy, Diazotrophy, Sphagnum moss, Peatland, Light

\section{Introduction}

The large amounts of carbon $(\mathrm{C})$ stored in Northern peatlands (representing 250-450 Pg C; Frolking and Roulet 2007) are severely threatened by anthropogenic disturbances of these vulnerable ecosystems due to for example drainage, fires and N-fertilization (Turetsky et al. 2002; Bragazza et al. 2012; Andersen et al. 2013; Abdalla et al. 2016; Leifeld and Menichetti 2018). Over millennia peatlands have acted as net $\mathrm{C}$-sinks, sequestering and storing more $\mathrm{C}$ than is emitted to the atmosphere, thereby counteracting global warming (Gorham 1991; Rydin and Jeglum 2006; Frolking and Roulet 2007; Loisel et al. 2014; Leifeld and Menichetti 2018). C is mainly stored as dead organic matter (Loisel et al. 2014) originating moss and

\footnotetext{
*Correspondence: maartje.vankessel@science.ru.nl

${ }^{1}$ Department of Microbiology, Radboud University, Heijendaalseweg 135, 6525 AJ Nijmegen, The Netherlands

Full list of author information is available at the end of the article
}

plants such as from Sphagnum mosses, Carex species that dominate many of these peatlands.

Most Sphagnum species thrive in nitrogen (N) limited environments (Aerts et al. 1992) and do so by monopolizing the majority of atmospheric $\mathrm{N}$ deposited (Fritz et al. 2014). Sphagnum has a high affinity for $\mathrm{N}\left(\mathrm{K}_{\mathrm{s}} 3.5-6.5 \mu \mathrm{M}\right)$ and will rapidly take up ammonium or nitrate when available (Fritz et al. 2014). In addition to the limited pool of environmentally available $\mathrm{N}, \mathrm{N}$ required for growth is also provided by microbial $\mathrm{N}_{2}$ fixation via Sphagnum-associated microorganisms, which may account for the mismatch between the high $\mathrm{N}$-content of Sphagnum mosses and the low input of N via atmospheric deposition (Vile et al. 2014). In younger peatlands, $\mathrm{N}_{2}$ fixation by methane-oxidizing microorganisms is assumed to be responsible for $\mathrm{N}$ accumulation in Sphagnum (Larmola et al. 2014), providing a strong link between the $\mathrm{CH}_{4}$-cycle and N-cycle in Sphagnum-dominated peatlands (Ho and Bodelier 2015).
Springer Open (c) The Author(s) 2020. This article is licensed under a Creative Commons Attribution 4.0 International License, which permits use, sharing, adaptation, distribution and reproduction in any medium or format, as long as you give appropriate credit to the original author(s) and the source, provide a link to the Creative Commons licence, and indicate if changes were made. The images or other third party material in this article are included in the article's Creative Commons licence, unless indicated otherwise in a credit line to the material. If material is not included in the article's Creative Commons licence and your intended use is not permitted by statutory regulation or exceeds the permitted use, you will need to obtain permission directly from the copyright holder. To view a copy of this licence, visit http://creativeco mmons.org/licenses/by/4.0/. 
Worldwide, the N-cycle in peatlands has been disturbed by long-term, anthropogenic $\mathrm{N}$ fertilization. This has reduced $\mathrm{C}$-accumulation rates and altered decomposition of stored organic matter (Bragazza et al. 2012) and ultimately leads to changes in the plant-community composition (Tomassen et al. 2004; Fritz et al. 2012). As N-fertilization skews the N:phosphorus (P) ratio in Sphagnum mosses, it was thought that additional P-fertilization might alleviate the effect of $\mathrm{N}$-fertilization. However, this appeared to be only partially true, as mosses remained $\mathrm{N}$-saturated and experienced $\mathrm{N}$-stress despite P-fertilization (Fritz et al. 2012). It is, however, clear that the $\mathrm{N}$-fertilization effect is strongly linked to nutrient stoichiometry, especially in relation to P-availability. Excess $\mathrm{N}$ and disturbance of the $\mathrm{N}: \mathrm{P}$ ratio can greatly affect the delicate balance between C-sink and C-source in peatlands (Turetsky et al. 2002; Frolking et al. 2011; Kivimäki et al. 2013).

The response of the nitrogen-fixing microbial community associated with Sphagnum mosses to $\mathrm{N}$-fertilization remains puzzling. Short-term high $\mathrm{N}$-fertilization has been shown to result in reduced $\mathrm{N}_{2}$ fixation activity in peatland Sphagnum mosses (Kox et al. 2016) as well as in forest mosses (Leppänen et al. 2013). Yet, long-term $\mathrm{N}$-fertilization has been shown to hardly affect $\mathrm{N}_{2}$ fixation in Sphagnum (Kox et al. 2016; van den Elzen et al. 2018). P-fertilization, on the other hand appears to stimulate $\mathrm{N}_{2}$ fixation activity of the associated microorganisms, but not necessarily Sphagnum moss growth (Fritz et al. 2012; van den Elzen et al. 2017; Rousk et al. 2017).

The $\mathrm{N}$-fertilization effect on $\mathrm{CH}_{4}$ oxidation activity depends largely on land use, and the extent and duration of fertilization (Veraart et al. 2015). For bog ecosystems, long term fertilization with $\mathrm{N}, \mathrm{P}$ and potassium (K) fertilization resulted in increased $\mathrm{CH}_{4}$ emission, mostly via indirect effects such as changes in vegetation structure and peat properties (Juutinen et al. 2018). However, P and $\mathrm{K}$ rather than $\mathrm{N}$ fertilization seemed to have contributed to this result, since the PK-only treatment of the study stimulated methanogenesis, whereas $\mathrm{N}$ fertilization did not affect $\mathrm{CH}_{4}$ production or consumption (Juutinen et al. 2018).

Next to N-fertilization, light intensity and its diurnal rhythm do affect C-sequestration by Sphagnum mosses (Laine et al. 2011; Kangas et al. 2014). Different Sphagnum species are adapted to different light and moisture conditions, which is reflected in their productivity (Kangas et al. 2014; Bengtsson et al. 2016). The diurnal rhythm of Sphagnum mosses influences the conditions in and around the mosses. Although there is little specific literature available on this diurnal effect on the Sphagnum microbiome, it is highly likely that the daily light regime affects the Sphagnum-associated microbiome (Larmola et al. 2014; van den Elzen et al. 2017).

In this study, the primary goal was to investigate the environmental drivers of $\mathrm{N}_{2}$ fixation and $\mathrm{CH}_{4}$ oxidation in pristine Sphagnum mosses. To this end, peat sods were collected from a pristine site in Northern Finland. Fertilization (control, $\mathrm{N}, \mathrm{P}$ or $\mathrm{N}+\mathrm{P}$ ), $\mathrm{CH}_{4}$, and light treatments were applied in a full factorial set-up to further disentangle the mechanisms controlling Sphagnum-associated $\mathrm{CH}_{4}$ oxidation and $\mathrm{N}_{2}$ fixation. It was expected that $\mathrm{N}$ fertilization would result in decreased $\mathrm{N}_{2}$ fixation activity, whereas $\mathrm{P}$ fertilization would show increased $\mathrm{N}_{2}$ fixation rates but not necessarily $\mathrm{CH}_{4}$ oxidation rates. Both $\mathrm{N}_{2}$ fixation and $\mathrm{CH}_{4}$ oxidation rates were expected to be higher in light conditions. $\mathrm{CH}_{4}$ addition on the other hand was expected to stimulate methane-oxidizing nitrogen-fixing microorganisms. Moss growth was expected to benefit from any type of fertilization as the mosses were collected from a pristine peat site and thus nutrient limited.

In a climate-controlled room, the peat sods received $\mathrm{N}$, $\mathrm{P}$, both $\mathrm{N}+\mathrm{P}$ fertilization or no fertilization at all (control) and received additional or no additional $\mathrm{CH}_{4}$. In addition, all measurements were performed in light and dark to test the influence of light. Both in the field and in the lab, we measured net gas fluxes of $\mathrm{CO}_{2}$ and $\mathrm{CH}_{4}$ in dark and light, and determined rates of microbial $\mathrm{N}_{2}$ fixation and $\mathrm{CH}_{4}$ oxidation rates in the dark and light using stable isotopes.

\section{Materials and methods Sampling site}

The sampling site was located in Siikajoki, Finland, a well-studied pristine peatland [ $\mathrm{N}$ deposition rate locally $0.3 \mathrm{~g} \mathrm{~m}^{-2}$ year ${ }^{-1}$; Mustajärvi et al. (2008)] located in the middle of the boreal ecoclimatic zone $\left(64^{\circ} 45^{\prime} \mathrm{N}\right.$, $24^{\circ} 42^{\prime}$ E; Tuittila et al. 2013; Larmola et al. 2014). At an oligotrophic fen site SJ4 (Laine et al. 2011) eight peat sods dominated by $S$. papillosum were collected $(50 \times 25 \times 20 \mathrm{~cm} ; \mathrm{l} \times \mathrm{w} \times \mathrm{h})$ and four $20 \mathrm{~L}$ vessels with peat water were collected and transported back to Nijmegen, the Netherlands, within $48 \mathrm{~h}$. Upon arrival in the laboratory, each peat sod was cut into 4 mesocosms which were immediately placed into glass aquaria $(25 \times 12 \times 30 \mathrm{~cm} ; \mathrm{l} \times \mathrm{w} \times \mathrm{h})$, creating 32 mesocosms $(25 \times 12 \times 20 \mathrm{~cm} ; 1 \times \mathrm{w} \times \mathrm{h})$. The water level was maintained at $10 \mathrm{~cm}$ below the moss surface, which was similar to the natural situation, using the peat water collected locally.

Mesocosms were kept at $15{ }^{\circ} \mathrm{C}$ by means of a water bath in a climate chamber (average $24^{\circ} \mathrm{C}$ ), and exposed to a $16 \mathrm{~h}$ light period per day (Philips greenpower LED,

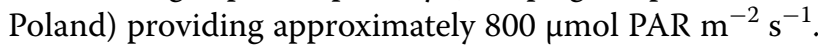


Mesocosms were acclimatized in the climate chamber for 6 weeks prior to experimental treatment.

\section{Experimental design}

Incubations for the determination of $\mathrm{N}_{2}$ fixation and $\mathrm{CH}_{4}$ oxidation rates, both in dark and light conditions, were performed. In the lab, a full factorial set-up was used to study the effect of fertilization, $\mathrm{CH}_{4}$ addition and light as specified in Table 1. Each treatment had 4 replicates, resulting in 32 individual mesocosms; samples originating from one sod did not get the same treatment. The fertilization treatments consisted of artificial rainwater Kox et al. (2016) with additional N fertilization $\left(25 \mathrm{~kg} \mathrm{~N} h a^{-1}\right.$ year $^{-1}$ as $\left.\mathrm{NH}_{4} \mathrm{NO}_{3}\right)$, P fertilization $\left(10 \mathrm{~kg} \mathrm{P} \mathrm{ha}{ }^{-1}\right.$ year $^{-1}$ as $\left.\mathrm{KH}_{2} \mathrm{PO}_{4}\right)$, or a combination of both (NP). The non-fertilized controls (C) received limited background levels of $\mathrm{N}$ and $\mathrm{P}$ (resp. $0.5 \mathrm{~kg} \mathrm{~N} \mathrm{ha}^{-1}$ year ${ }^{-1}$ as $\mathrm{NH}_{4} \mathrm{NO}_{3}$ and $0.2 \mathrm{~kg} \mathrm{P} \mathrm{ha}^{-1}$ year $^{-1}$ as $\mathrm{KH}_{2} \mathrm{PO}_{4}$ ). $\mathrm{N}$ fertilization was applied by sprinkling the fertilized rainwater on top of the moss layer, whereas $P$ fertilization was supplied via parallel injections ( 25 times) $1.5 \mathrm{~cm}$ below the moss surface mimicking subsurface P fertilization. For the methane treatment, mesocosms received methane $\left(1.3 \mathrm{mmol} \mathrm{CH}_{4} \mathrm{~L}^{-1}\right)$ dissolved in artificial rainwater, via the bottom of the mesocosm once a week $(1 \mathrm{~L})$. In the control treatment, dissolved Argon was added instead of $\mathrm{CH}_{4}$. The amount of rainwater provided was equalized to the mean annual rainfall in Northern Finland [521 $\mathrm{mm}_{\text {year }}{ }^{-1}$; Drebs et al. (2002)]. The experiment lasted for 10 weeks.

\section{Porewater and moss chemistry}

Porewater samples were collected via Rhizons $(0.2 \mu \mathrm{m}$; $5 \mathrm{~cm}$ length in the field; Eijkelkamp Agrisearch Equipment, Giesbeek, the Netherlands). Porewater $\mathrm{pH}$, alkalinity, concentrations of $\mathrm{PO}_{4}{ }^{3-}, \mathrm{NO}_{3}{ }^{-}, \mathrm{NH}_{4}{ }^{+}$and elemental composition were analyzed as described by Van

\begin{tabular}{|c|c|c|c|c|}
\hline Treatment & $\mathrm{CH}_{4}$ & $\begin{array}{l}\text { Concentration N } \\
\left(\mathrm{kg} \mathrm{ha}^{-1} \text { year }^{-1}\right)\end{array}$ & $\begin{array}{l}\text { Concentration } \mathrm{P} \\
\left(\mathrm{kg} \mathrm{ha}^{-1} \text { year }^{-1}\right)\end{array}$ & $\mathbf{n}$ \\
\hline Control & No & 0.5 & 0.2 & 4 \\
\hline N & No & 25 & 0.2 & 4 \\
\hline$P$ & No & 0.5 & 10 & 4 \\
\hline$N+P$ & No & 25 & 10 & 4 \\
\hline Control $+\mathrm{CH}_{4}$ & Yes & 0.5 & 0.2 & 4 \\
\hline $\mathrm{N}+\mathrm{CH}_{4}$ & Yes & 25 & 0.2 & 4 \\
\hline $\mathrm{P}+\mathrm{CH}_{4}$ & Yes & 0.5 & 10 & 4 \\
\hline $\mathrm{N}+\mathrm{P}+\mathrm{CH}_{4}$ & Yes & 25 & 10 & 4 \\
\hline
\end{tabular}

Effects of light/dark were measured in light or dark periods in the climate room den Elzen et al. (2017). DOC and TN were determined by combustion (Shimadzu, Duisburg, Germany). Upper $3 \mathrm{~cm}$ of three Sphagnum specimens were sampled for total $\mathrm{N}, \mathrm{P}$ and $\mathrm{K}$ concentrations in moss tissue, which was analyzed as described by Van den Elzen et al. (2017). All data is presented in Additional file 1: Table S1.

\section{Total gas flux analysis}

In the mesocosms, total fluxes of $\mathrm{CO}_{2}$ and $\mathrm{CH}_{4}$ in light and dark were measured using a Picarro G2508 Greenhouse Gas Analyzer with cavity ringdown spectroscopy (Picarro Inc., Santa Clara, CA, USA). When measuring fluxes, mesocosms were closed air-tight using a lid and paste (Terostat IX, Teroson GmbH, Heidelberg, Germany). Temperature and light conditions were logged using a $\mathrm{HOBO}$ pendant temperature and light logger (Onset, Bourne, MA, USA). Fluxes are expressed as $\mathrm{mg} \mathrm{m}^{-2} \mathrm{~h}^{-1}$ for measured rates, but as $\mathrm{mg} \mathrm{m}^{-2}$ day $^{-1}$ for diurnal fluxes, calculated based on $8 \mathrm{~h}$ dark and $16 \mathrm{~h}$ light regime.

\section{Moss performance}

In each mesocosm 2 sticks were placed and marked to determine the height increase of the moss surface. Sphagnum surface height increase relative to each stick was recorded every 2 weeks.

\section{${ }^{15} \mathrm{~N}_{2}$ fixation and ${ }^{13} \mathrm{CH}_{4}$ oxidation rates}

For each activity assay, mosses (top $3 \mathrm{~cm}$ length) were carefully collected from each mesocosm. Per incubation three moss parts were put in a $120 \mathrm{ml}$ serum vial, closed with a butyl rubber stopper and crimp capped. To determine nitrogen fixation activity, batch incubations were supplied with $15 \%$ labelled ${ }^{15} \mathrm{~N}-\mathrm{N}_{2}$. Another set of incubations received ${ }^{13} \mathrm{C}$-labeled $\mathrm{CH}_{4}$ (5\%) which was additionally to the $15 \%$ labelled ${ }^{15} \mathrm{~N}-\mathrm{N}_{2}$ to determine $\mathrm{CH}_{4}$ oxidation potential. Incubations were kept for $48 \mathrm{~h}$ at $24{ }^{\circ} \mathrm{C}$ either in the light or in the dark. After incubation, mosses were oven-dried for $48 \mathrm{~h}$ at $70{ }^{\circ} \mathrm{C}$ and dried material was ground using a mixer mil (MM301, Retsch, Germany) for $2 \mathrm{~min}$ at 30 rotations s $\mathrm{s}^{-1}$. To determine the fraction of ${ }^{15} \mathrm{~N}$ or ${ }^{13} \mathrm{C}$, plant biomass was taken (resp. 5 and $0.225 \mathrm{mg}$ ) in duplicates and analyzed for ${ }^{15} \mathrm{~N}$ and ${ }^{13} \mathrm{C}$ content using an elemental (CNS) analyzer coupled to an Isotopic Ratio Mass Spectrometer as described in Kox et al. (2018).

\section{Statistical analysis}

Data was analyzed using $\mathrm{R}$ version 3.4.0 ( $\mathrm{R}$ Development Core Team 2017). Each treatment consisted of 4 replicates (Table 1). Normality of data was tested using Shapiro-Wilk's test on the residual (stats-package) and homogeneity of variance was tested using Levene's test 
(car-package). Data following a normal distribution were analyzed using ANOVA followed by Tukey HSD post hoc test. In case of non-normal or heteroscedastic data, data was transformed prior to analysis. This was the case for $\mathrm{N}$-content (1/n transformation), $\mathrm{CO}_{2}$ flux and $\mathrm{CH}_{4}$ flux in both light and dark conditions (log transformation), ${ }^{15} \mathrm{~N}-\mathrm{N}_{2}$ fixation (log transformed), ${ }^{13} \mathrm{C}-\mathrm{CH}_{4}$ oxidation (log-transformed). Data whose distribution remained unaffected upon transformation (C-content, P-content, Porewater) were analyzed using non-parametric tests (Kruskal-Wallis followed by Dunn test).

\section{Results}

Here we investigate the environmental drivers of microbial $\mathrm{N}_{2}$ fixation and $\mathrm{CH}_{4}$ oxidation in pristine Sphagnum mosses. Fertilization treatment (Control, N, P, and NP) as well as addition of $\mathrm{CH}_{4}$ and effect of light were applied to further disentangle the mechanisms controlling Sphagnum-associated $\mathrm{CH}_{4}$ oxidation and $\mathrm{N}_{2}$ fixation.

\section{$\mathrm{CH}_{4}$ addition effect}

The weekly addition of dissolved $\mathrm{CH}_{4}$ did not significantly change the overall concentration of dissolved $\mathrm{CH}_{4}$ in the mesocosms $\left(\mathrm{CH}_{4}\right.$ addition $510 \pm 42 \mu \mathrm{mol} \mathrm{L}^{-1}$ $($ mean $\pm \mathrm{SEM})$; no-addition $471 \pm 31 \mu \mathrm{mol} \mathrm{L}^{-1}$; Additional file 1: Figure $\mathrm{S} 1, \mathrm{~F}_{1,24}=0.5, \mathrm{p}>0.05$ ), indicating

Table 2 Sphagnum moss growth $\left(\mathrm{mm} \mathrm{day}{ }^{-1}\right)$ for each treatment

\begin{tabular}{llll}
\hline Treatment & \multicolumn{2}{l}{ Moss growth $\left(\mathbf{m m ~ d a y}^{\mathbf{- 1}}\right)$} & \\
\cline { 2 - 3 } & Mean \pm SEM & \\
\hline Control & $0.47 \pm 0.05$ & ns & 8 \\
$N$ & $0.38 \pm 0.03$ & ns & 8 \\
$N+P$ & $0.46 \pm 0.03$ & ns & 8 \\
$P$ & $0.42 \pm 0.02$ & ns & 8 \\
\hline
\end{tabular}

ns not significant

a $\mathrm{CH}_{4}$ addition treatment was merged with its control, resulting in doubling of the replicates that sufficient endogenous methane was being produced during the 10 weeks of incubation. Therefore, the results from the $\mathrm{CH}_{4}$ addition and control without methane additions mesocosms were merged in the further analysis, which results in an increase of the number of replicates (resulting in a duplication of samples from 4 to 8 , as also indicated in Tables 4, 5 and 6) for each fertilization treatment and light or dark treatment.

\section{NP fertilization effect}

The mosses grew on average $0.43 \pm 0.02 \mathrm{~mm} \mathrm{day}^{-1}$ (equaling $3 \mathrm{~cm}$ in 10 weeks; Table 2). Moss growth was not affected by 10 weeks of $\mathrm{N}, \mathrm{P}$ or $\mathrm{N}+\mathrm{P}$ fertilization ( $p>0.05)$. C content of the mosses (range 434$444 \mathrm{mg} \mathrm{C} \mathrm{g}^{-1}$ dry weight (DW), Table 3) was not affected by the fertilization treatments $\left(\chi^{2}(3)=1.6, p>0.05\right)$, and neither were porewater dissolved organic carbon (DOC, 86-110 ppm) and total N (TN, 1.7-1.9 ppm) (Table 4; $\left.\mathrm{DOC} \mathrm{F}_{3,28}=0.82, \mathrm{p}>0.05 ; \mathrm{TN} \mathrm{F}_{3,28}=0.36, \mathrm{p}>0.05\right)$.

The $\mathrm{N}$ content of $\mathrm{N}$-fertilized moss (Table 3; N-fertilized $8.1 \pm 0.3 \mathrm{mg} \mathrm{N} \mathrm{g}^{-1}$; NP fertilized $7.8 \pm 0.2 \mathrm{mg} \mathrm{N} \mathrm{g}^{-1}$ ) was about $10 \%$ higher $\left(\mathrm{F}_{3,123}=4.6, \mathrm{p}<0.005\right)$ than those of the control and P fertilized plants (control 7.2 $\pm 0.1 \mathrm{mg} \mathrm{N}$ $\mathrm{g}^{-1}$; P fertilized $7.4 \pm 0.2 \mathrm{mg} \mathrm{N} \mathrm{g} \mathrm{g}^{-1}$ ). K-content of the moss biomass showed the opposite pattern, with $\mathrm{N}$ fertilized mosses containing $18 \%$ less $\mathrm{K}\left(\mathrm{F}_{3,123}=7.87\right.$, $\mathrm{p}<0.001)$ compared to non- $\mathrm{N}$-fertilized treatments (Table 3). Analysis of the moss $\mathrm{P}$ content revealed that NP fertilized mosses contained $16 \%$ more $P$ than all other treatments (Table 3, $\left.\mathrm{X}^{2}(3)=21.7, \mathrm{p}<0.001\right)$.

\section{$\mathrm{CO}_{2}$ and $\mathrm{CH}_{4}$ fluxes}

$\mathrm{CO}_{2}$ and $\mathrm{CH}_{4}$ fluxes were measured, diurnal fluxes are presented in rates per day and flux rates are presented per hour. The $\mathrm{CO}_{2}$ flux (see Fig. 1a) measured both in dark and light conditions did not differ between treatments (Dark $\mathrm{F}_{3,27}=0.26, \mathrm{p}>0.05$; Light $\mathrm{F}_{3,28}=0.33, \mathrm{p}>0.05$; Fig. 1a). Overall, diurnal fluxes of all mesocosms showed

Table 3 C, N, P, and K contents of Sphagnum moss tissue

\begin{tabular}{|c|c|c|c|c|c|c|c|c|c|}
\hline \multirow[t]{2}{*}{ Treatment } & \multicolumn{2}{|c|}{$\mathrm{C}$ content $\left(\mathrm{mg} \mathrm{C} \mathrm{g}^{-1}\right)$} & \multicolumn{2}{|c|}{$\mathrm{N}$ content $\left(\mathrm{mg} \mathrm{N} \mathrm{g}^{-1}\right)$} & \multicolumn{2}{|c|}{$\mathrm{P}$ content $\left(\mathrm{mg} \mathrm{P} \mathrm{g}^{-1}\right)$} & \multicolumn{2}{|c|}{$\mathrm{K}$ content $\left(\mathrm{mg} \mathrm{K} \mathrm{g}^{-1}\right)$} & \multirow[t]{2}{*}{$n^{a}$} \\
\hline & Mean $\pm S E$ & & Mean $\pm S$ & & Mean \pm SEN & & Mean \pm & & \\
\hline Control & $444 \pm 2.9$ & ns & $7.2 \pm 0.1$ & $a$ & $0.49 \pm 0.02$ & $a$ & $7.6 \pm 0.3$ & $a c$ & 32 \\
\hline N & $440 \pm 2.0$ & ns & $8.1 \pm 0.3$ & $b$ & $0.47 \pm 0.01$ & $a$ & $6.4 \pm 0.2$ & $b$ & 32 \\
\hline$N+P$ & $434 \pm 10$ & ns & $7.8 \pm 0.2$ & $a b$ & $0.57 \pm 0.02$ & $b$ & $6.5 \pm 0.2$ & $a b$ & 32 \\
\hline P & $443 \pm 2.0$ & ns & $7.4 \pm 0.2$ & $a$ & $0.50 \pm 0.04$ & $a$ & $8.3 \pm 0.5$ & $c$ & 32 \\
\hline
\end{tabular}

For each measured element the differences between treatments are indicated with italic letters, identical letters indicate no difference

ns not significant

a As $\mathrm{n}$ was the same for each measurement it is only mentioned once here. $\mathrm{CH}_{4}$ addition treatment was merged with its control, resulting in doubling of the replicates 
Table 4 Porewater DOC and TN content (ppm) for each treatment

\begin{tabular}{|c|c|c|c|c|c|c|}
\hline \multirow[t]{2}{*}{ Treatment } & \multicolumn{3}{|l|}{ DOC (ppm) } & \multicolumn{3}{|l|}{ TN (ppm) } \\
\hline & Mean \pm SEM & $n^{a}$ & & Mean \pm SEM & $n^{a}$ & \\
\hline Control & $110 \pm 14$ & 8 & ns & $1.91 \pm 0.15$ & 8 & ns \\
\hline N & $93 \pm 13$ & 8 & ns & $1.71 \pm 0.15$ & 8 & ns \\
\hline$N+P$ & $104 \pm 10$ & 8 & ns & $1.87 \pm 0.16$ & 8 & ns \\
\hline$P$ & $86 \pm 9.3$ & 8 & ns & $1.76 \pm 0.17$ & 8 & ns \\
\hline
\end{tabular}

ns not significant

a $\mathrm{CH}_{4}$ addition treatment was merged with its control, resulting in doubling of the replicates

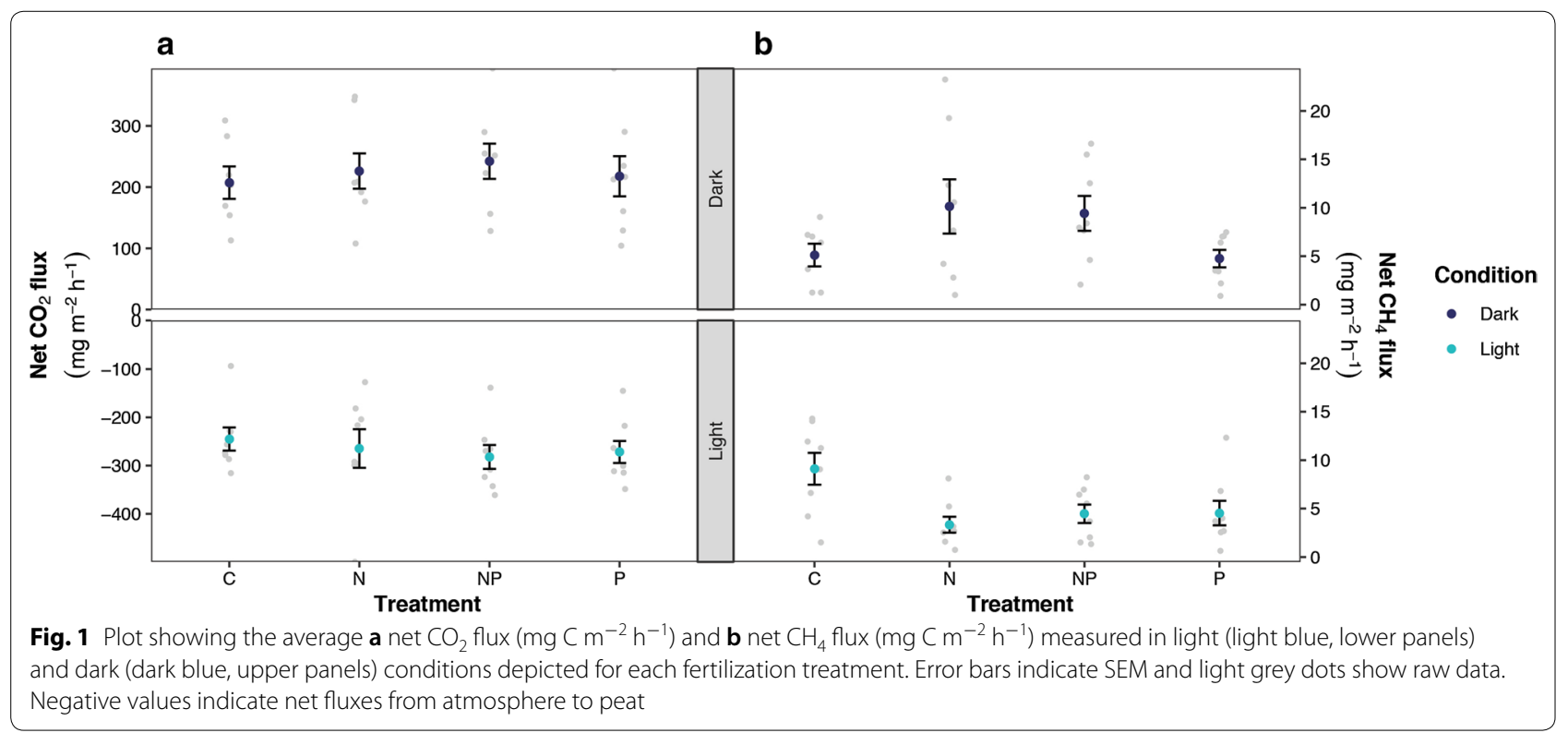

Table 5 Net diurnal $\mathrm{CO}_{2}$ flux $\left(\mathrm{mg} \mathrm{C} \mathrm{m}^{-2}\right.$ day $\left.^{-1}\right)$ based on a 16 h-8 h light-dark cycle

\begin{tabular}{lll}
\hline Treatment & $\begin{array}{l}\text { Net diurnal } \mathbf{C O}_{\mathbf{2}} \text { flux } \\
\left(\mathbf{m g ~ C ~} \mathbf{~ m}^{-\mathbf{2}} \mathbf{d a y}^{-1}\right)\end{array}$ \\
\cline { 2 - 3 } & Mean \pm SEM & $\mathbf{n}$ \\
\hline Control & $-2298 \pm 362$ & 7 \\
$N$ & $-2423 \pm 489$ & 8 \\
$N+P$ & $-2574 \pm 324$ & 8 \\
$P$ & $-2606 \pm 378$ & 8 \\
\hline
\end{tabular}

Negative numbers indicate net uptake

$\mathrm{CH}_{4}$ addition treatment was merged with its control, resulting in doubling of the replicates

that these are acting as net $\mathrm{CO}_{2}$ sinks with an average net $\mathrm{CO}_{2}$ intake of $2.5 \pm 1.9 \mathrm{mg} \mathrm{C} \mathrm{m}^{-2}$ day $^{-1}$ (Table 5).

The $\mathrm{CH}_{4}$ flux (see Fig. 1b) measured in light conditions was 2.2 times lower in $\mathrm{N}$ fertilized $(\mathrm{N}$ and $\mathrm{N}+\mathrm{P})$ mesocosms (resp. $\mathrm{N} 3.3 \pm 0.8 \mathrm{mg} \mathrm{C} \mathrm{m} \mathrm{m}^{-2} \mathrm{~h}^{-1}$ and
NP $4.5 \pm 1.0 \mathrm{mg} \mathrm{C} \mathrm{m}^{-2} \mathrm{~h}^{-1)}$ compared to non-fertilized mesocosms (control; 9.1 $\pm 1.7 \mathrm{mg} \mathrm{C} \mathrm{m}^{-2} \mathrm{~h}^{-1}$; $\mathrm{F}_{3,28}=4.44, \quad \mathrm{p}=0.01$ ). Furthermore, the $\mathrm{N}$ fertilized mesocosms showed a higher $\mathrm{CH}_{4}$ flux in the dark (10 $\pm 3 \mathrm{mg} \mathrm{C} \mathrm{m}^{-2} \mathrm{~h}^{-1}$ ), compared to in the light $\left(3.3 \pm 0.9 \mathrm{mg} \mathrm{C} \mathrm{m}^{-2} \mathrm{~h}^{-1} ; \mathrm{F}_{1,48}=4.25, \mathrm{p}<0.05\right)$. The control mesocosms on the other hand showed a lower $\mathrm{CH}_{4}$ flux in the dark $\left(5.1 \pm 1.1 \mathrm{mg} \mathrm{C} \mathrm{m}^{-2}\right.$ day $\left.^{-1}\right)$, compared to the light $\left(9.1 \pm 1.7 \mathrm{mg} \mathrm{C} \mathrm{m}^{-2}\right.$ day $^{-1}$; see Fig. 1b), which is unlike the fertilized mesocosms. Overall, diurnal $\mathrm{CH}_{4}$ fluxes showed mesocosms were a net source of $\mathrm{CH}_{4}$, with reduced methane emission up to $30 \%$ upon $\mathrm{N}$ or $\mathrm{P}$ fertilization (Table 6).

\section{$\mathrm{N}_{2}$ fixation}

In the field incubation, $\mathrm{N}_{2}$ fixation rates were 3 times higher in the light than in the dark (resp. 409 \pm 112 versus $135 \pm 55 \mathrm{nmol} \mathrm{N}_{2} \mathrm{~g}^{-1} \mathrm{DW}$ day $^{-1} ; \mathrm{F}_{1,14}=5.47$, $\mathrm{p}<0.05$; see Fig. 2). This effect was also observed in the mesocosm experiment $\left({ }^{15} \mathrm{~N}-\mathrm{N}_{2} \quad \mathrm{~F}_{3,58}=28.23, \mathrm{p}<0.001\right.$; 
Table 6 Net diurnal $\mathrm{CH}_{4}$ flux (mg C m${ }^{-2}$ day $^{-1}$ ) based on a $16 \mathrm{~h}-8 \mathrm{~h}$ light-dark cycle

\begin{tabular}{lll}
\hline Treatment & $\begin{array}{l}\text { Net diurnal CH4 flux } \\
\left(\mathbf{m g ~ C ~ m}^{-2} \text { day }^{-1}\right)\end{array}$ \\
\cline { 2 - 3 } & Mean \pm SEM & $\mathbf{n}$ \\
\hline Control & $192 \pm 34$ & 7 \\
N & $134 \pm 29$ & 8 \\
N + P & $147 \pm 23$ & 8 \\
P & $111 \pm 26$ & 8 \\
\hline
\end{tabular}

Positive numbers indicate net efflux

$\mathrm{CH}_{4}$ addition treatment was merged with its control, resulting in doubling of the replicates

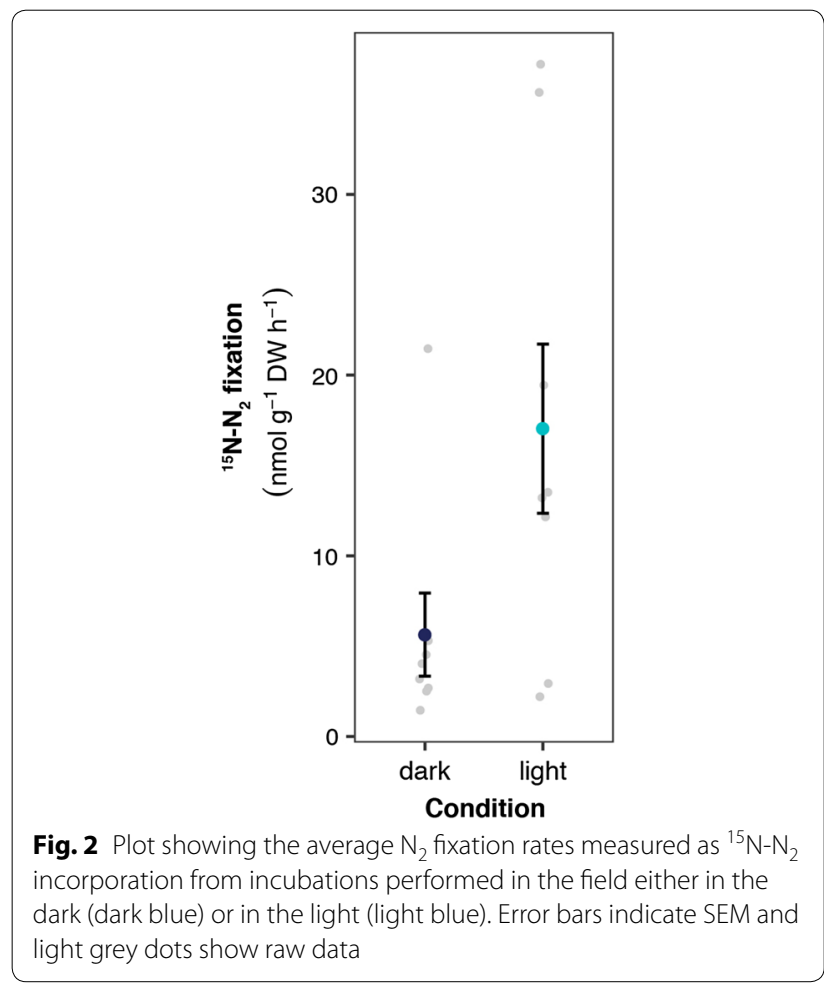

${ }^{15} \mathrm{~N}-\mathrm{N}_{2}+{ }^{13} \mathrm{C}-\mathrm{CH}_{4} \quad \mathrm{~F}_{3.54}=12.70, \mathrm{p}<0.001$; see Fig. 3), where both treatments $\left(\mathrm{N}\right.$ and $\left.\mathrm{N}+\mathrm{CH}_{4}\right)$ showed lowest $\mathrm{N}_{2}$ fixation rates in the dark $\left({ }^{15} \mathrm{~N}-\mathrm{N}_{2}: 21.3 \pm 2.1 \mathrm{nmol} \mathrm{N}\right.$ ${ }_{2} \mathrm{~g}^{-1} \mathrm{DW}$ day ${ }^{-1} ;{ }^{15} \mathrm{~N}-\mathrm{N}_{2}+{ }^{13} \mathrm{C}-\mathrm{CH}_{4}: 23.7 \pm 2.1 \mathrm{nmol} \mathrm{N}$ ${ }_{2} \mathrm{~g}^{-1} \mathrm{DW}$ day $\left.^{-1}\right)$ and highest rates in the light $\left({ }^{15} \mathrm{~N}-\mathrm{N}_{2}\right.$. $89.0 \pm 14 \mathrm{nmol} \mathrm{N}_{2} \mathrm{~g}^{-1} \mathrm{DW}$ day $^{-1} ;{ }^{15} \mathrm{~N}-\mathrm{N}_{2}+{ }^{13} \mathrm{C}_{-} \mathrm{CH}_{4}: 54$. $9 \pm 10 \mathrm{nmol} \mathrm{N}_{2} \mathrm{~g}^{-1} \mathrm{DW}$ day $^{-1}$ ). None of the fertilization treatments differed from each other. Yet, it seems that mesocosms which received $\mathrm{P}$ and NP fertilization have higher $\mathrm{N}_{2}$ fixation rates on average, even though these are not significantly higher than for the $\mathrm{N}$-fertilization or control.

\section{$\mathrm{CH}_{4}$ oxidation}

$\mathrm{CH}_{4}$ oxidation rates as measured by ${ }^{13} \mathrm{C}-\mathrm{CH}_{4}$ incorporation, showed a highly similar pattern to $\mathrm{N}_{2}$ fixation rates. $\mathrm{CH}_{4}$ oxidation was lowest in the dark (81 $\pm 37 \mathrm{nmol} \mathrm{CH}_{4} \mathrm{~g}^{-1}$ DW h${ }^{-1}$ Fig. 4) and five times higher in the light $\left(423 \pm 64 \mathrm{nmol} \mathrm{CH}_{4} \mathrm{~g}^{-1} \mathrm{DW} \mathrm{h}{ }^{-1}\right.$; $\left.\mathrm{F}_{1,59}=134.25, \mathrm{p}<0.001\right)$. The low $\mathrm{CH}_{4}$ oxidation rate in the dark correlates with high $\mathrm{CH}_{4}$ efflux in the dark. Similar to $\mathrm{N}_{2}$ fixation rates, there was no difference in $\mathrm{CH}_{4}$ oxidation between fertilization treatments.

\section{Discussion}

This study aimed to investigate the effect of various potential environmental drivers on moss growth and associated microbial $\mathrm{N}_{2}$ fixation and $\mathrm{CH}_{4}$ oxidation. Hereto, we fertilized the moss $(\mathrm{N}, \mathrm{P}$ and $\mathrm{N}+\mathrm{P})$ under ambient and increased $\mathrm{CH}_{4}$ concentrations. Additionally, the effect of light was studied. $\mathrm{CH}_{4}$ addition did not increase $\mathrm{CH}_{4}$ concentrations in the mesocosms, indicating that there was always a significant amount of $\mathrm{CH}_{4}$ produced by the methanogenic archaea in the sods. Although fertilization increased nutrient contents in moss tissue, no effect on Sphagnum moss growth was found. In the used set-up, microbial $\mathrm{N}_{2}$ fixation and $\mathrm{CH}_{4}$ oxidation were clearly positively affected by light.

\section{Effects of $\mathrm{CH}_{4}$ on $\mathrm{N}_{2}$ fixation rates}

According to our results, it seems that internal $\mathrm{CH}_{4}$ production in the peat sods was already so high that the addition of $\mathrm{CH}_{4}$ became insignificant. Compared to other studies the concentration of $\mathrm{CH}_{4}$ present in the porewater of the mesocosms was already very high $\left(491 \pm 26 \mu \mathrm{mol} \mathrm{CH} \mathrm{CH}_{4} \mathrm{~L}^{-1}\right)$, which is similar to the reported maximum values of $407 \pm 83 \mu \mathrm{mol} \mathrm{CH}_{4} \mathrm{~L}^{-1}$ (Kip et al. 2012) and more than ten times higher than the $41 \mu \mathrm{mol} \mathrm{CH}_{4} \mathrm{~L}^{-1}$ reported by Putkinen et al. (2014). Similar to $\mathrm{CH}_{4}$ addition in the mesocosms, $\mathrm{N}_{2}$ fixation was also not affected by $\mathrm{CH}_{4}$ addition in the isotope incubations.

\section{Fertilization effects}

Fertilization did not affect $\mathrm{CO}_{2}$ fluxes, but decreased $\mathrm{CH}_{4}$ fluxes in the light, yet measured $\mathrm{CH}_{4}$ oxidation rates were not different between the different fertilization treatments. The moderate effect of $\mathrm{N}$ and $\mathrm{P}$ fertilization on nutrient content and absence of substantial effects on moss growth might indicate that 10 weeks of fertilization may have been too short to observe an effect. Therefore, a longer period of fertilization or 


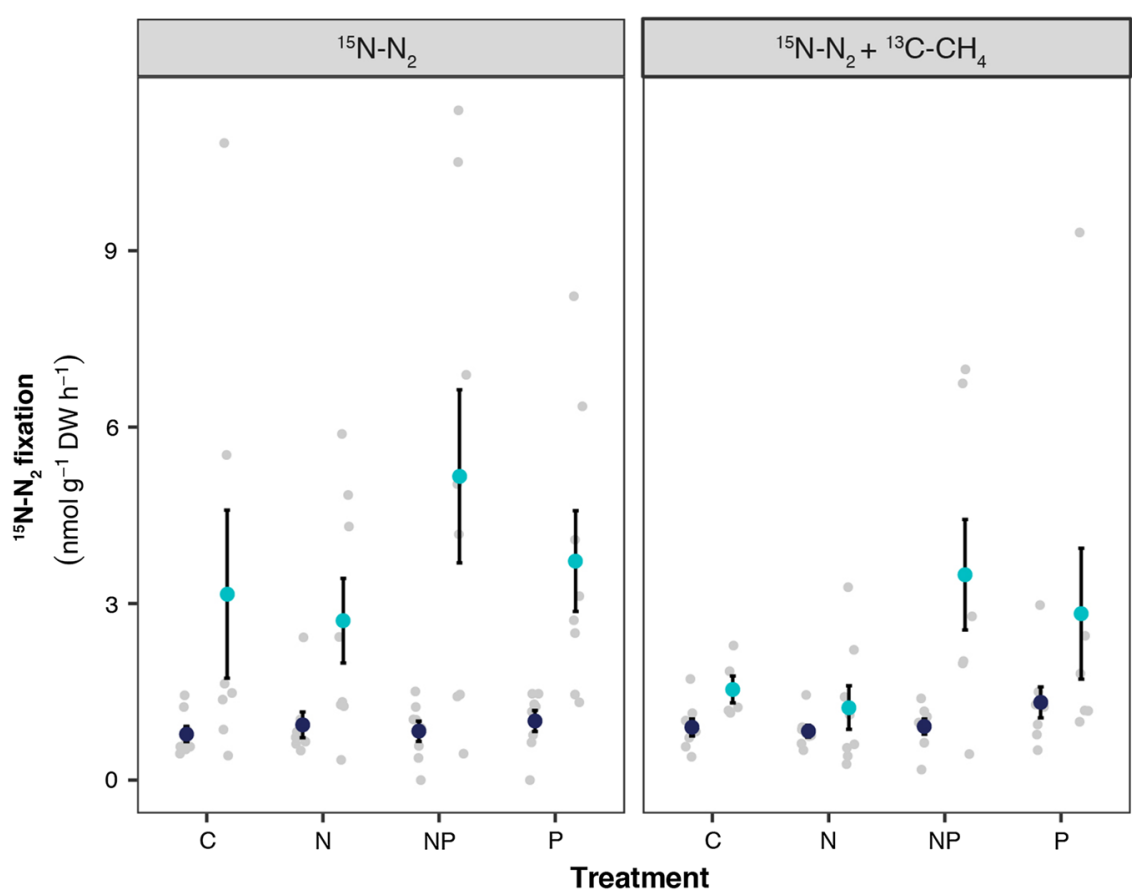

\section{Condition}

- dark

- light

Fig. 3 Plot showing the average $\mathrm{N}_{2}$ fixation rates measured as ${ }^{15} \mathrm{~N}-\mathrm{N}_{2}$ incorporation for incubation with ${ }^{15} \mathrm{~N}-\mathrm{N}_{2}$ (left panel) and ${ }^{15} \mathrm{~N}-\mathrm{N}_{2}+{ }^{13} \mathrm{C}-\mathrm{CH}$ (right panel) displayed per fertilization treatment. Incubations were performed either in the dark (dark blue) or in the light (light blue). Error bars indicate SEM and light grey dots show raw data

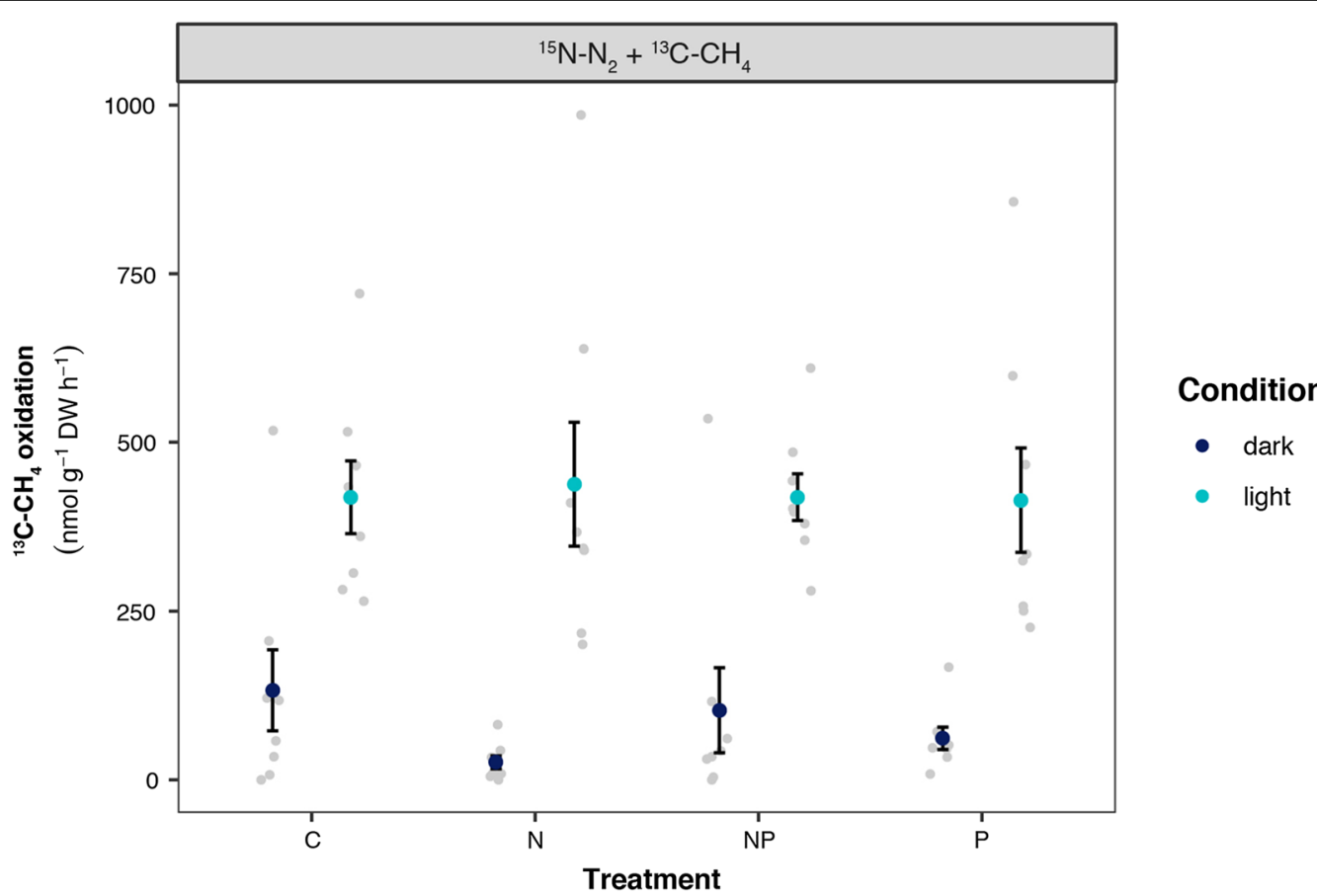

Fig. 4 Plot showing the average $\mathrm{CH}_{4}$ oxidation rates measured as ${ }^{13} \mathrm{C}_{-} \mathrm{CH}_{4}$ incorporation at the end of the experiment, displayed per fertilization treatment. Incubations were performed either in the dark (dark blue) or in the light (light blue). Error bars indicate SEM and light grey dots show raw data 
intensified fertilization is advised for future studies and would probably have resulted in notable fertilization effects.

In addition, we supplied $\mathrm{P}$ to the mesocosms via injection just below the moss surface (capitula). Although this way of P-fertilization is dissimilar to other studies (Limpens et al. 2004; Fritz et al. 2012; van den Elzen et al. 2017), it resembles the way increased $P$ fluxes enter peat ecosystems in reality. P-fertilization is in most studies sprinkled on top of the mosses or added in the inflowing surface water. These often resulted in a clear P fertilization effect (Fritz et al. 2012; van den Elzen et al. 2017). Most of the surface water entering a peatland, does not reach the capitulum level but only reaches the lower part of the moss. Furthermore, inflow of $\mathrm{P}$ into a fen is mostly via surface water. In order to mimick this inflow from $\mathrm{P}$ in our mesocosms setup, we decided to inject $\mathrm{P}$ instead of sprinkling it on top of the peat sods. The manner of $\mathrm{P}$ fertilization does seem to matter for its effect on the plant (Rydin and Clymo 1989). When P fertilization is applied on top of the capitulum more than $90 \%$ of the $\mathrm{P}$ will remain in the capitulum, whereas fertilization below the capitulum is translocated upwards to the stem and the capitulum and will therefore also become diluted (Rydin and Clymo 1989). If the P fertilization dilutes due to injection below the capitulum, we would have had to fertilize $\mathrm{P}$ for a longer period of time to observe any effect. Furthermore, by injecting P-fertilization and sprinkling $\mathrm{N}$-fertilization we separated the two nutrient sources physically from each other. It might be that the physical separation also contributed to the limited fertilization effect. In addition, $\mathrm{N}$ and $\mathrm{P}$ fertilization should be repeated for a longer period to further test their effects on methane oxidation and nitrogen fixation. In order to compare the results to other studies, these two fertilizers should maybe be added in the same manner.

\section{Light as a key driver of $\mathrm{N}_{\mathbf{2}}$ fixation}

Three times higher microbial $\mathrm{N}_{2}$ fixation rates and five times higher $\mathrm{CH}_{4}$ oxidation rates in the presence of light indicate that these processes are strongly stimulated by photosynthesis, either directly or indirectly. For leguminous plant species it has recently been reported that the plants modulate their carbon allocation to symbiotic nitrogen-fixing Rhizobia in response to both light an $\mathrm{N}$ availability (Friel and Friesen 2019). For $\mathrm{N}_{2}$ fixation associated with Sphagnum, it has been observed before that $\mathrm{N}_{2}$ fixation rates are highest under illuminated conditions (Larmola et al. 2014; van den Elzen et al. 2017). This is true even though $\mathrm{N}_{2}$ fixation is inhibited by presence of $\mathrm{O}_{2}$ (Vitousek et al. 2013). Due to the $\mathrm{O}_{2}$ respiration by the moss in the dark, $\mathrm{O}_{2}$ availability is low in the dark (Kangas et al. 2014), hence dark conditions are in theory more beneficial for $\mathrm{N}_{2}$ fixation. This therefore generates two hypotheses: either $\mathrm{N}_{2}$ fixation activity is mainly performed by phototrophic cyanobacteria, which are most active in light conditions, or the nitrogen-fixing community is (directly or indirectly) dependent on photosynthates produced by the Sphagnum moss in light-conditions. The mechanisms behind this can be disentangled in future research by studying which part of the nitrogen-fixing community is active in the dark versus light by using RNA analysis on the nifH gene.

\section{Light as a key driver of $\mathrm{CH}_{4}$ oxidation}

The net $\mathrm{CH}_{4}$ flux is controlled by the $\mathrm{CH}_{4}$ oxidation activity pattern in light and dark. The lower $\mathrm{CH}_{4}$ oxidation activity observed in the dark explains the higher net $\mathrm{CH}_{4}$ flux from the mesocosms in the dark. The lightdependency of moss-associated methanotrophy has been reported before in Sphagnum (Larmola et al. 2014) as well as brown-mosses (Liebner et al. 2011), and it has been reported in a Danish wetland (King 1990), but remains unexplained so-far. Furthermore, $\mathrm{N}$ or $\mathrm{P}$ fertilization seem to stimulate net $\mathrm{CH}_{4}$ emission in dark but reduces net $\mathrm{CH}_{4}$ emission in light, resulting in a lower $\mathrm{CH}_{4}$ efflux. The extra nutrients in the fertilized mesocosms are causing discrepancy in $\mathrm{CH}_{4}$ oxidation and emission and further underline the intricate role of photosynthesis in the overall $\mathrm{CH}_{4}$ cycle in Sphagnum-dominated peatlands.

We postulate four hypotheses for light-dependent $\mathrm{CH}_{4}$ oxidation observed here. Like $\mathrm{N}_{2}$ fixation, $\mathrm{CH}_{4}$ oxidation is either (1) directly or (2) indirectly dependent on photosynthates produced by moss (and associated photosynthetic microorganisms). In the case of indirect dependency, the photosynthates are affecting another part of the microbial community that the methanotroph subsequently benefits from (Oswald et al. 2015). Regardless of the nature of the dependency, most phototrophs (plants and cyanobacteria) are known to excrete photosynthetic products such as malate, citrate, glycolic acid and methanol (Tolbert and Zill 1956; Nalewajko 1966; Fall and Benson 1996; Meyer et al. 2010; Vorholt 2012). The excretion of carbohydrates is furthermore increased upon photoinhibition to dispose of electrons. Photoinhibition has been shown to occur in Sphagnum and is estimated to result in lowered $\mathrm{C}$ accumulation rates (Murray et al. 1993; Mazziotta et al. 2019). Especially in summer, in peatlands in the northern hemisphere photoinhibition might occur, because of the long days and strong light intensity.

The third (3) hypothesis is that $\mathrm{CH}_{4}$ oxidation is directly coupled to microbial photosynthesis (anoxygenic), which has been postulated in the 1960s (Vishniac 1960; Wertlieb and Vishniac 1967) but so far not 
been experimentally proven yet (Ward et al. 2019). The process has only been reported for Rhodopseudomonas gelatinosa (Wertlieb and Vishniac 1967) but the observed activity was low. A recent study presented metagenomic evidence for the capability of anoxygenic phototrophy by the WPS2 phylum. This phylum, without culture representatives is abundant in the Sphagnum microbiome (Holland-Moritz et al. 2018). Methane would be a suitable and abundant electron donor for anoxygenic phototrophy in peatland ecosystems, much more abundant than the common electron donor in anoxygenic phototrophy, which is sulfide.

The fourth (4) hypothesis is that the methanotrophs might benefit from light-dependent $\mathrm{CH}_{4}$ production, which has been observed in oligotrophic lakes (Grossart et al. 2011) and might as well occur in oligotrophic peatlands. This production of $\mathrm{CH}_{4}$ in daytime in oxygenated lakes has been postulated to be of cyanobacterial origin by cleaving methyl-phosphonates (Tang et al. 2016; Bižić-Ionescu et al. 2020; Günthel et al. 2019). In this way, methanotrophs could thrive when it's light due to higher concentrations of both $\mathrm{CH}_{4}$ and $\mathrm{O}_{2}$ as a result of oxygenic photosynthesis. In the control treatment of our experiment, $\mathrm{CH}_{4}$ emission rates were indeed almost twice as high in light conditions.

Our study focused on Sphagnum-associated $\mathrm{CH}_{4}$ oxidation and $\mathrm{N}_{2}$ fixation, and the effects of $\mathrm{N}, \mathrm{P}$ and $\mathrm{N}+\mathrm{P}$ fertilization, $\mathrm{CH}_{4}$ addition and the additional effect of light. Light was shown to be a strong driver of both $\mathrm{N}_{2}$ fixation and $\mathrm{CH}_{4}$ oxidation, which indicates that both processes benefit directly or indirectly from photosynthesis. Leakage of photosynthates produced by the Sphagnum and associated photosynthetic microbial partners might be a good $\mathrm{C}$-source for the organisms active in $\mathrm{CH}_{4}$ oxidation and $\mathrm{N}_{2}$ fixation. To test the various postulated hypotheses, future research should take a closer look upon the light-dependency of both $\mathrm{CH}_{4}$ oxidation and $\mathrm{N}_{2}$ fixation by measuring changes in activity based upon light on smaller timescales and intervals.

\section{Supplementary information}

Supplementary information accompanies this paper at https://doi. org/10.1186/s13568-020-00994-9.

Additional file 1. Supplementary material containing Table S1 and Figure S1.

\section{Acknowledgements}

We thank Anna M. Laine for help with arranging the sampling in Finland. Sebastian Krosse and Paul van der Ven from the General Instruments Department Radboud University are thanked for help with elemental analysis of porewater and stable isotope analysis of moss material. David Smit is thanked for help with in the lab with all the treatments in the mesocosm experiment.

\section{Authors' contributions}

MK Conceptualization, investigation, methodology, formal analysis, data curation, visualization, writing and editing original draft; EvdE Conceptualization, investigation, methodology, formal analysis, data curation; LL Conceptualization, resources, editing and reviewing, supervision; MJ Conceptualization, funding acquisition and resources, editing and reviewing, supervision; MvK Conceptualization, editing and reviewing, supervision. MARK and EvdE executed the experiments. MARK and EvdE analyzed the data. MARK, MSMJ, $\mathrm{LL}$ and MAHJVK wrote the manuscript. All authors discussed the results and commented and agreed on the manuscript. All authors read and approved the final manuscript

\section{Funding}

MARK was supported by European Research Council Ecomom 339880 to M.S.M.J., who was further supported by the Netherlands Organization for Scientific Research (SIAM Gravitation grant 024002002 and Spinoza Award). MAHJvK was supported by a NWO veni grant (016.veni.192.062).

\section{Availability of data and materials}

Supplemental data are provided.

\section{Ethics approval and consent to participate}

This article does not contain any studies with human participants or animals performed by any of the authors.

\section{Competing interests}

All authors declare to have no conflict of interest.

\section{Author details}

${ }^{1}$ Department of Microbiology, Radboud University, Heijendaalseweg 135, 6525 AJ Nijmegen, The Netherlands. ${ }^{2}$ Department of Aquatic Ecology and Environmental Biology, Radboud University, Heijendaalseweg 135, 6525 AJ Nijmegen, The Netherlands.

Received: 8 January 2020 Accepted: 16 March 2020

Published online: 31 March 2020

\section{References}

Abdalla M, Hastings A, Truu J, Espenberg M, Mander Ü, Smith P (2016) Emissions of methane from northern peatlands: a review of management impacts and implications for future management options. Ecol Evol 6:7080-7102. https://doi.org/10.1002/ece3.2469

Aerts R, Wallen B, Malmer N (1992) Growth-limiting nutrients in Sphagnumdominated bogs subject to low and high atmospheric nitrogen supply. J Ecol 80:131-140

Andersen R, Chapman SJ, Artz RRE (2013) Microbial communities in natural and disturbed peatlands: a review. Soil Biol Biochem 57:979-994. https:// doi.org/10.1016/j.soilbio.2012.10.003

Bengtsson F, Granath G, Rydin H (2016) Photosynthesis, growth, and decay traits in Sphagnum - a multispecies comparison. Ecol Evol 6:3325-3341. https://doi.org/10.1002/ece3.2119

Bižić-Ionescu M, Klintzsch T, lonescu D, Hindiyeh MY, Günthel M, Muro-Pastor AM, Eckert W, Urich T, Keppler F, Grossart H-P (2020) Aquatic and terrestrial cyanobacteria produce methane. Sci Adv 6:3aax5343. https://doi. org/10.1126/sciadv.aax5343

Bragazza L, Buttler A, Habermacher J, Brancaleoni L, Gerdol R, Fritze H, Hanajík P, Laiho R, Johnson D (2012) High nitrogen deposition alters the decomposition of bog plant litter and reduces carbon accumulation. Glob Chang Biol 18:1163-1172. https://doi.org/10.111 1/j.1365-2486.2011.02585.x

Development Core Team R (2017) R: a language and environment for statistical computing. R Found. Stat. Comput, Vienna

Drebs A, Nordlund A, Karlsson P, Helminen J, Rissanen P (2002) Climatological statistics of Finland 1971-2000. Clim Stat Finl 1:1-99

Fall R, Benson AA (1996) Leaf methanol—the simplest natural product from plants. Trends Plant Sci 1:296-301. https://doi.org/10.1016/S1360 $-1385(96) 88175-0$ 
Friel CA, Friesen ML (2019) Legumes modulate allocation to rhizobial nitrogen fixation in response to factorial light and nitrogen manipulation. Front Plant Sci 10:1-9. https://doi.org/10.3389/fpls.2019.01316

Fritz C, van Dijk G, Smolders AJP, Pancotto VA, Elzenga TJTM, Roelofs JGM, Grootjans AP (2012) Nutrient additions in pristine Patagonian Sphagnum bog vegetation: can phosphorus addition alleviate (the effects of) increased nitrogen loads. Plant Biol 14:491-499. https://doi.org/10.111 1/j.1438-8677.2011.00527.x

Fritz C, Lamers LPM, Riaz M, van den Berg LJL, Elzenga TJTM (2014) Sphagnum mosses - masters of efficient n-uptake while avoiding intoxication. PLoS ONE 9:1-11. https://doi.org/10.1371/journal.pone.0079991

Frolking S, Roulet NT (2007) Holocene radiative forcing impact of northern peatland carbon accumulation and methane emissions. Glob Chang Biol 13:1079-1088

Frolking S, Talbot J, Jones MC, Treat CC, Kauffman JB, Tuittila ES, Roulet N (2011) Peatlands in the Earth's 21st century climate system. Environ Rev 19:371-396

Gorham E (1991) Northern peatlands: role in the carbon cycle and probable responses to climatic warming. Ecol Appl 1:182-195

Grossart H-P, Frindte K, Dziallas C, Eckert W, Tang KW (2011) Microbial methane production in oxygenated water column of an oligotrophic lake. Proc Natl Acad Sci USA 108:19657-19661. https://doi.org/10.1073/pnas.11107 16108

Günthel M, Donis D, Kirillin G, lonescu D, Bizic M, McGinnis DF, Grossart H, Tang KW (2019) Contribution of oxic methane production to surface methane emission in lakes and its global importance. Nat Commun 10:5497. https ://doi.org/10.1038/s41467-019-13320-0

Ho A, LE Bodelier P (2015) Diazotrophic methanotrophs in peatlands: the missing link? Plant Soil 389:185-196. https://doi.org/10.1007/s1110 4-015-2393-9

Holland-Moritz H, Stuart J, Lewis LR, Miller S, Mack MC, McDaniel SF, Fierer N (2018) Novel bacterial lineages associated with boreal moss species. Environ Microbiol 20:2625-2638. https://doi.org/10.1111/1462-2920.14288

Juutinen S, Moore TR, Bubier JL, Arnkil S, Humphreys E, Marincak B, Roy C, Larmola T (2018) Long-term nutrient addition increased $\mathrm{CH}_{4}$ emission from a bog through direct and indirect effects. Sci Rep 8:3838. https://doi. org/10.1038/s41598-018-22210-2

Kangas L, Maanavilja L, Hájek T, Juurola E, Chimner RA, Mehtätalo L, Tuittila ES (2014) Photosynthetic traits of Sphagnum and feather moss species in undrained, drained and rewetted boreal spruce swamp forests. Ecol Evol 4:381-396. https://doi.org/10.1002/ece3.939

King GM (1990) Regulation by light of methane emissions from a wetland. Nature 345:513-515. https://doi.org/10.1038/345513a0

Kip N, Fritz C, Langelaan ES, Pan Y, Bodrossy L, Pancotto V, Jetten MSM, Smolders AJP, Op den Camp HJM (2012) Methanotrophic activity and diversity in different Sphagnum magellanicum dominated habitats in the southernmost peat bogs of Patagonia. Biogeosciences 9:47-55

Kivimäki SK, Sheppard LJ, Leith ID, Grace J (2013) Long-term enhanced nitrogen deposition increases ecosystem respiration and carbon loss from a Sphagnum bog in the Scottish Borders. Environ Exp Bot 90:53-61. https:// doi.org/10.1016/j.envexpbot.2012.09.003

Kox MAR, Lüke C, Fritz C, van den Elzen E, van Alen T, Op den Camp HJM, Lamers LPM, Jetten MSM, Ettwig KF (2016) Effects of nitrogen fertilization on diazotrophic activity of microorganisms associated with Sphagnum magellanicum. Plant Soil. https://doi.org/10.1007/s11104-016-2851-z

Kox MAR, Aalto SL, Penttilä T, Ettwig KF, Jetten MSM, van Kessel MAHJ (2018) The influence of oxygen and methane on nitrogen fixation in subarctic Sphagnum mosses. AMB Expr 8:76. https://doi.org/10.1186/s1356 8-018-0607-2

Laine AM, Juurola E, Hájek T, Tuittila E-S (2011) Sphagnum growth and ecophysiology during mire succession. Oecologia 167:1115-1125. https:// doi.org/10.1007/s00442-011-2039-4

Larmola T, Leppänen SM, Tuittila E-S, Aarva M, Merilä P, Fritze H, Tiirola M (2014) Methanotrophy induces nitrogen fixation during peatland development. Proc Natl Acad Sci USA 111:734-739. https://doi.org/10.1073/pnas.13142 84111

Leifeld J, Menichetti L (2018) The underappreciated potential of peatlands in global climate change mitigation strategies. Nat Commun 9:1071. https ://doi.org/10.1038/s41467-018-03406-6

Leppänen SM, Salemaa M, Smolander A, Mäkipää R, Tiirola M (2013) Nitrogen fixation and methanotrophy in forest mosses along a $\mathrm{N}$ deposition gradient. Environ Exp Bot 90:62-69. https://doi.org/10.1016/j.envex pbot.2012.12.006

Liebner S, Zeyer J, Wagner D, Schubert C, Pfeiffer EM, Knoblauch C (2011) Methane oxidation associated with submerged brown mosses reduces methane emissions from Siberian polygonal tundra. J Ecol 99:914-922. https://doi.org/10.1111/j.1365-2745.2011.01823.x

Limpens J, Berendse F, Klees H (2004) How phosphorus availability affects the impact of nitrogen deposition on Sphagnum and vascular plants in bogs. Ecosystems 7:793-804. https://doi.org/10.1007/s10021-004-0274-9

Loisel J, Yu Z, Beilman DW, Camill P, Alm J, Amesbury MJ, Anderson D, Andersson S, Bochicchio C, Barber K, Belyea LR, Bunbury J, Chambers FM, Charman DJ, De Vleeschouwer F, Fiałkiewicz-Kozieł B, Finkelstein SA, Gałka M, Garneau M, Hammarlund D, Hinchcliffe W, Holmquist J, Hughes P, Jones MC, Klein ES, Kokfelt U, Korhola A, Kuhry P, Lamarre A, Lamentowicz M, Large D, Lavoie M, MacDonald G, Magnan G, Mäkilä M, Mallon G, Mathijssen P, Mauquoy D, McCarroll J, Moore TR, Nichols J, O'Reilly B, Oksanen P, Packalen M, Peteet D, Richard PJH, Robinson S, Ronkainen T, Rundgren M, Sannel ABK, Tarnocai C, Thom T, Tuittila ES, Turetsky M, Väliranta M, van der Linden M, van Geel B, van Bellen S, Vitt D, Zhao Y, Zhou W (2014) A database and synthesis of northern peatland soil properties and Holocene carbon and nitrogen accumulation. Holocene 24:1028-1042. https ://doi.org/10.1177/0959683614538073

Mazziotta A, Granath G, Rydin H, Bengtsson F, Norberg J (2019) Scaling functional traits to ecosystem processes: towards a mechanistic understanding in peat mosses. J Ecol 107:843-859. https://doi. org/10.1111/1365-2745.13110

Meyer S, De Angeli A, Fernie AR, Martinoia E (2010) Intra- and extra-cellular excretion of carboxylates. Trends Plant Sci 15:40-47. https://doi. org/10.1016/j.tplants.2009.10.002

Murray KJ, Tenhunen JD, Nowak RS (1993) Photoinhibition as a control on photosynthesis and production. Oecologia 96:200-207

Mustajärvi K, Merilä P, Derome J, Lindroos AJ, Helmisaari HS, Nöjd P, Ukonmaanaho L (2008) Fluxes of dissolved organic and inorganic nitrogen in relation to stand characteristics and latitude in Scots pine and Norway spruce stands in Finland. Boreal Environ Res 13(suppl. B):3-21

Nalewajko C (1966) Photosynthesis and excretion in various planktonic algae. Limnol Oceanogr 11:1-10. https://doi.org/10.4319/lo.1966.11.1.0001

Oswald K, Milucka J, Brand A, Littmann S, Wehrli B, Kuypers MMM, Schubert CJ (2015) Light-dependent aerobic methane oxidation reduces methane emissions from seasonally stratified lakes. PLoS ONE 10:1-22. https://doi. org/10.1371/journal.pone.0132574

Putkinen A, Larmola T, Tuomivirta T, Siljanen HMP, Bodrossy L, Tuittila E-S, Fritze $H$ (2014) Peatland succession induces a shift in the community composition of Sphagnum-associated active methanotrophs. FEMS Microbiol Ecol 88:596-611. https://doi.org/10.1111/1574-6941.12327

Rousk K, Degboe J, Michelsen A, Bradley R, Bellenger J-P (2017) Molybdenum and phosphorus limitation of moss-associated nitrogen fixation in boreal ecosystems. N Phytol 214:97-107. https://doi.org/10.1111/nph.14331

Rydin H, Clymo RS (1989) Transport of carbon and phosphorus compounds about Sphagnum. Proc R Soc B Biol Sci 237:63-84. https://doi. org/10.1098/rspb.1989.0037

Rydin H, Jeglum JK (2006) The biology of peatlands. Oxford University Press, Oxford

Tang KW, McGinnis DF, lonescu D, Grossart H-P (2016) Methane production in oxic lake waters potentially increases aquatic methane flux to air. Environ Sci Technol Lett 3:227-233. https://doi.org/10.1021/acs.estlett.6b00150

Tolbert NE, Zill LP (1956) Excretion of glycolic acid by algae during photosynthesis. J Biol Chem 222:895-906

Tomassen HBM, Smolders AJP, Limpens J, Lamers LPM, Roelofs JGM (2004) Expansion of invasive species on ombrotrophic bogs: desiccation or high N deposition? J Appl Ecol 41:139-150. https://doi.org/10.111 1/j.1365-2664.2004.00870.x

Tuittila ES, Juutinen S, Frolking S, Väliranta M, Laine AM, Miettinen A, Seväkivi ML, Quillet A, Merilä P (2013) Wetland chronosequence as a model of peatland development: vegetation succession, peat and carbon accumulation. Holocene 23:25-35. https://doi.org/10.1177/0959683612450197

Turetsky M, Wieder K, Halsey L, Vitt D (2002) Current disturbance and the diminishing peatland carbon sink. Geophys Res Lett 29:1526. https://doi. org/10.1029/2001GL014000

van den Elzen E, Kox MAR, Harpenslager SF, Hensgens G, Fritz C, Jetten MSM, Ettwig KF, Lamers LPM (2017) Symbiosis revisited: phosphorus and acid 
buffering stimulate $\mathrm{N}_{2}$ fixation but not Sphagnum growth. Biogeosciences 14:1111-1122. https://doi.org/10.5194/bg-14-1111-2017

van den Elzen E, van den Berg LJL, van der Weijden B, Fritz C, Sheppard $L$, Lamers LPM (2018) Effects of airborne ammonium and nitrate pollution strongly differ in peat bogs, but symbiotic nitrogen fixation remains unaffected. Sci Total Environ 610-611:732-740. https://doi.org/10.1016/j.scito tenv.2017.08.102

Veraart AJ, Steenbergh AK, Ho A, Kim SY, Bodelier PLE (2015) Beyond nitrogen: the importance of phosphorus for $\mathrm{CH}_{4}$ oxidation in soils and sediments. Geoderma 259-260:337-346. https://doi.org/10.1016/j.geode rma.2015.03.025

Vile MA, Wieder R, Živković T, Scott KD, Vitt DH, Hartsock JA, losue CL, Quinn JC, Petix M, Fillingim HM, Popma JM, Dynarski KA, Jackman TR, Albright CM, Wykoff DD (2014) N2-fixation by methanotrophs sustains carbon and nitrogen accumulation in pristine peatlands. Biogeochemistry 121:317-328. https://doi.org/10.1007/s10533-014-0019-6

Vishniac W (1960) Extraterrestrial microbiology. Aviat Sp Environ Med $31: 678-680$
Vitousek PM, Menge DNL, Reed SC, Cleveland CC (2013) Biological nitrogen fixation: rates, patterns and ecological controls in terrestrial ecosystems. Philos Trans R Soc Lond B Biol Sci 368:20130119. https://doi.org/10.1098/ rstb.2013.0119

Vorholt JA (2012) Microbial life in the phyllosphere. Nat Rev Microbiol 10:828-840. https://doi.org/10.1038/nrmicro2910

Ward L, Shih PM, Hemp J, Kakegawa T, Fischer WW, McGlynn SE (2019) Phototrophic methane oxidation in a member of the Chloroflexi phylum. bioRxiv. https://doi.org/10.1101/531582

Wertlieb D, Vishniac W (1967) Methane utilization by a strain of Rhodopseudomonas gelatinosa. J Bacteriol 93:1722-1724

\section{Publisher's Note}

Springer Nature remains neutral with regard to jurisdictional claims in published maps and institutional affiliations.

\section{Submit your manuscript to a SpringerOpen ${ }^{\odot}$ journal and benefit from:}

- Convenient online submission

- Rigorous peer review

- Open access: articles freely available online

- High visibility within the field

- Retaining the copyright to your article

Submit your next manuscript at $\boldsymbol{\nabla}$ springeropen.com 